\title{
Research Summary of Enterprise R\&D Team Human Capital
}

\author{
Wu Zenghai, Liu Chang* \\ International Business School of Shaanxi Normal University \\ Xi'an, Shaanxi \\ Email: 1752018745@163.com
}

\begin{abstract}
In the era of knowledge economy, the traditional theory of human capital is facing new requirements and challenges. Under this background, the team human capital gradually appeared in the research field of scholars. Based on summarizing previous researches, this paper defines the concept of R\&D team human capital, and analyzes the components of R\&D team human capital and the measurement of $R \& D$ team human capital components. And look into the direction of future research.
\end{abstract}

Keywords-R\&D team human capital; Concept; Constituent elements; Measurement

\section{INTRODUCTION}

In the era of knowledge economy, knowledge has become an important source of corporate competitive advantage. Scientific and technological enterprises mainly focus on R\&D and innovation of science and technology. Compared with traditional enterprises, science and technology companies often have complex tasks and high technological content. The skills and knowledge of individual employees alone are not enough to complete the project $\mathrm{R} \& \mathrm{D}$ tasks. Therefore, more and more technology-based companies have begun to pay attention to team building. The R\&D team is generally a group composed of several people. There are often differences in knowledge, experience, and abilities among the members. At present, the analysis of the human capital of enterprise teams in the theoretical circle is still based on the analysis framework of senior management, and lack of human capital analysis based on R\&D team. Moreover, there is no unified and widely accepted definition of team human capital, and its extension is also very vague. Therefore, this paper intends to construct the R\&D team's human capital composition and measurement on the basis of a large number of combing documents and to look into the direction of future research.

\section{R\&D TEAM HUMAN CAPITAL CONCEPT}

In the 1950s, Schultz pointed out that through human investment in education, training, and job migration, longterm benefits will be generated. Schultz (1961) believes that human capital is formed by investment and reflected in human beings. It is expressed as human knowledge, skills, qualifications, experience and proficiency, etc., which are combined into human qualities. Becker (2002) proposed that human capital refers to the knowledge, information, ideas, skills, and health that individuals possess. Youndt \& Snell (2004) believe that human capital mainly refers to the knowledge, skills, and expertise of individual employees. At present, the definition of individual human capital in the academic community is mainly based on the definition of Schultz and Becker and extends. The knowledge of team human capital is not the same.

In a broad sense, team human capital is the sum of team human capital and individual human capital. In a narrow sense, team human capital is only part of team human capital. The individual human capital in the R\&D team mainly refers to the knowledge stock, expertise, ability, and health that have an economic value that affects the future benefits of individuals through the investment of human capital such as education, training, medical care, and other human resources. The sum of quality factors such as status.

In the study of Akira Aoki (1984), he believes that some skills can only be formed in the team, and this special skill is not personally dedicated. Essentially, it is a kind of public goods. Individuals can neither be monopolized nor possessed. Ottorino Chillemi (1997) explicitly put forward the concept of team human capital for the first time, extended the human capital to the team basis, and specifically discussed the key points and renegotiation issues after the formation of the team's human capital, and he focused on this issue. The team's human capital integrity and team members' moral hazard issues. He sees the team as a form of organizational choice in which the company saves on the collection, processing, and transmission of information. The non-material assets in the team are seen as the team's human capital. Hou Fengyun (2006), on the basis of summarizing the team theory, defined the connotation of team human capital and pointed out that team human capital refers to serving the team's production and management, and the joint investment of enterprises and individuals can create lasting benefits for the company. Sexual benefits condense team-specific knowledge, skills, etc. within the team as a whole. It mainly includes team-specific communication and team-specific knowledge, team-shared skills including man-machine interaction skills, team spirit, culture, and team practices. Ge Yuhui (2011) proposed in the study of the senior management team that through the cultivation of the sense of responsibility, integrity, and cooperation of the members of the senior management team to

This work was supported by a grant from Shaanxi soft science research program in 2015 (2015KRM096). 
improve the ability structure of the senior management team, the team's human capital is formed [1]. Gu Qinxuan (2011) thinks that team human capital refers to all the knowledge, skills, and abilities of the members of a team. The team's human capital can be measured by personal qualifications, job title, performance, work experience, and other qualifications [2]. Li Xiaoqing (2014) believes that the values, ethical sense, and sense of responsibility of team human capital have a decisive influence on the production activities of the company. In the study of the relationship between innovative human capital and corporate competitive advantage [3]. Gao Suying (2016) extended the organizational nature of the VRIO analysis framework to the team level to explore knowledge, technology, and capabilities at the team level from a resourcebased perspective [4]. Exclusivity defines innovative human capital as the organization's human capital resources that help companies achieve their innovative strategic goals within the enterprise's economic boundaries, with knowledge, expertise and innovation capability embedded in R\&D team members and with team-specific expertise. Ability to.

\section{R \& D TEAM HUMAN CAPITAL COMPOSITION AND MEASUREMENT}

\section{A. $R \& D$ team human capital components}

The high-lady theory proposed by Harm brick and Mason (1984) believes that the educational background, work experience, and background and the overall diversity (heterogeneity) of the senior management team affect the perception and values of the company's management team, and the values influence the company's strategic choice by the limited rationality. That is, demographic variables are used to measure the human capital of the executive team. Richard and Shelor (2002) believe that the age structure of team members is the former dependent variable of the company's sales. Wang Shenghai (2010) started researching team human capital from an age perspective. Taylor (1975) and Flood et al. (1997) found that with the increase of the average age and the rich social experience and work experience of senior management, their ability to integrate resources and respond to risks will increase accordingly, thus promoting the more confident and radical in the strategic planning, which is beneficial to the improvement of the enterprise value. Finkelstein et al. (1996) found that the extension of the term of office will reduce the communication costs within the team and promote the integration of ideas, which will have a significant impact on business performance. Tihanyi et al. (2000) found that the higher the level of education of the team, the better the access and use of valuable information, the more helpful it is to formulate strategies. Chen Zhongwei and Chang Ji (2009) studied the influence of job title heterogeneity and team cooperation. Li Jianjun (2015), etc., in an empirical study of the characteristics of entrepreneurial team human capital and high-tech companies R\&D investment, confirmed that the level of $R \& D$ investment is negatively correlated with the average age of senior management teams, and is significantly positively correlated with the average academic qualifications and technical background of senior executives. Select the average age, average academic record, and technical background of the senior management team as the variables of the human capital of the senior management team [5]. Zhan Menglin et al. (2016) pointed out in an empirical study on the human capital structure of entrepreneurial teams and the performance of entrepreneurial firms. In the human capital structure of entrepreneurial teams, their integrity and heterogeneity have a significant impact on entrepreneurial performance, but the impact is different [6]. The structure of the human capital of the entrepreneurial team is constructed from eight aspects of the integration and heterogeneity from four perspectives: age, industry experience, professional experience, and education experience.

Li Ting and Zhang Huiyan (2008) incorporated value orientation into the scope of team human capital. Wu Ping (2003) also considers values and attitudes as part of the team's human capital. Chen Kai and Lin Feng (2015) studied the formation path and influencing factors of the human capital of entrepreneurial teams. Three dimensions of knowledge, skills and capabilities are studied from the individual to the formation of the team. It is pointed out that team atmosphere and power allocation have a positive impact on the human capital appreciation of the entrepreneurial team. Technologybased R\&D team employees are highly educated knowledge workers. In the process of converting individual knowledge into team knowledge, employees' personal values, team atmosphere, and willingness to share influence other factors. Ding Zhikun (2009) conducted a study on the Chinese construction industry team. The structural equation model validates the conclusion that the attitude to knowledge sharing is more likely to affect the willingness of architects to share knowledge than subjective norms. Therefore, team managers should pay more attention to training team members to have a positive attitude towards knowledge sharing so as to increase knowledge. Sharing behavior. Gong Liqun (2013) studied the knowledge-sharing motives of knowledge providers in virtual teams. The empirical analysis shows that self-worth is the intrinsic motivation of the knowledge-sharing behavior of knowledge providers in virtual teams, and he puts emphasis on incentive mechanisms based on intrinsic motivation. When the economic motivation fails, intrinsic motivation such as selfworth can promote the knowledge sharing behavior of team members. American scholar Spencer proposed a famous model of quality iceberg in 1993. The so-called "iceberg model" is to divide the different manifestations of the individual's personal qualities into the surface "above the iceberg" and the deep "bottom of the iceberg." Among them, "the part above the iceberg" includes basic knowledge and basic skills. It is an external performance, and it is easy to understand and measure. It is relatively easy to change and develop through training. The "below the iceberg" includes social roles, self-image, characteristics, and motives. It is an intrinsic and hard-to-measure part of people. They are not easily changed by external influences, but they play a key role in human behavior and performance.

In order to sum up relevant researches on the content of human capital of enterprise teams by various scholars, the human capital of $R \& D$ team of technology enterprise is divided into two parts based on the perspective of iceberg model. The sections above the iceberg mainly include factors such as age, gender, educational level, work experience, 
industry experience, and professional technology. And analyze the homogeneity and heterogeneity of the above factors. The following sections of the iceberg include factors such as team members' values, attitudes, personality, and motivation that are difficult to measure.

\section{B. Measurement of $R \& D$ Team Human Capital}

For the measurement of team human capital, different scholars have different research focuses and the measurement dimensions given are also different. The measurement of the above part of the iceberg refers to the influence of Zhan Menglin (2016) on the human capital structure of entrepreneurial teams on the performance of entrepreneurial companies. The specific meaning of each variable is shown in Table 1.

TABLE I. THE MEANING OF VARIOUS VARIABLES ON THE ICEBERG

\begin{tabular}{|c|c|c|}
\hline Variable type & Variable name & Variable meaning \\
\hline \multirow{4}{*}{$\begin{array}{l}\text { Human } \\
\text { capital } \\
\text { integrity }\end{array}$} & Average age & Average Age $=$ Age of R\&D Team Members and Divide by Team Size \\
\hline & $\begin{array}{l}\text { Average work } \\
\text { experience }\end{array}$ & $\begin{array}{c}\text { The value is the length of the work after the team member enters the company, } \\
\text { calculated in years. } \\
\text { Average Work Experience }=\text { R\&D Team Work Experience and Divide by } \\
\text { Team Size }\end{array}$ \\
\hline & Average education level & $\begin{array}{l}\text { The value is the average of the highest academic qualifications earned by team } \\
\text { members. The degree of education is measured using the Likert five-point } \\
\text { scoring method. Among them, high school, technical secondary school and the } \\
\text { following educational qualifications take 1; college degree takes } 2 \text {; university } \\
\text { bachelor's degree takes 3; master's graduate student takes the value 4; doctoral } \\
\text { graduate students and above take 5 }\end{array}$ \\
\hline & $\begin{array}{c}\text { Industry experience } \\
\text { average }\end{array}$ & $\begin{array}{c}\text { The value is the length of time that the team member engages in the related } \\
\text { industry before entering the company and is calculated in units of years. } \\
\text { Industry Experience Mean = R\&D Team Industry Experience and Divide Team } \\
\text { Size }\end{array}$ \\
\hline \multirow{4}{*}{$\begin{array}{l}\text { Human } \\
\text { Capital } \\
\text { Heterogeneity }\end{array}$} & Age heterogeneity & $\begin{array}{l}\text { The value is the difference in the age of the R\&D team members. Since age is a } \\
\text { continuous variable, the standard difference coefficient calculation method is } \\
\text { used to derive the age heterogeneity among members. The larger the value is, } \\
\text { the greater the age difference is. }\end{array}$ \\
\hline & $\begin{array}{c}\text { Work experience } \\
\text { heterogeneity }\end{array}$ & $\begin{array}{l}\text { The value is the difference of the team members' working time in the company. } \\
\text { It is a continuous variable in years. Therefore, the standard deviation } \\
\text { coefficient calculation method is used to obtain the heterogeneity of work } \\
\text { experience among members. The larger the value, the work of the } \\
\text { representative members. The greater the difference in experience. }\end{array}$ \\
\hline & $\begin{array}{c}\text { Educational } \\
\text { heterogeneity }\end{array}$ & $\begin{array}{l}\text { The value is the difference between the highest academic qualifications earned } \\
\text { by members of the entrepreneurial team. The qualification is calculated using } \\
\text { Likert's quintile method, so the educational experience heterogeneity is a non- } \\
\text { continuous variable, using Herfindahl's index (calculated as: } H_{\mathrm{i}}=1-\sum X_{\mathrm{i}}^{2} \text { where } \mathrm{i} \\
\text { represents a certain characteristic variable. The value of } \mathrm{H} \text { is between } 0-1 \text {, The } \\
\text { larger the value of } \mathrm{H} \text {, the greater the discreteness of the variable, ie, the greater } \\
\text { the heterogeneity. The greater the value, the greater the heterogeneity of } \\
\text { education among members. }\end{array}$ \\
\hline & $\begin{array}{c}\text { Educational } \\
\text { heterogeneity }\end{array}$ & $\begin{array}{l}\text { The value is the difference of the working time of the team members in the } \\
\text { relevant industry before entering the company. It is a continuous variable in } \\
\text { years. Therefore, the standard deviation coefficient calculation method is used } \\
\text { to obtain the heterogeneity of work experience among members. The larger the } \\
\text { value, The greater the difference in working experience of the representative } \\
\text { members }\end{array}$ \\
\hline
\end{tabular}

The measurement of icebergs can use the mature scale of previous studies. The scale developed by Karen (1999) is mainly used to measure the values of members and their views on work. The research scales developed by Hsu et al. and Harris et al. mainly measure the interpersonal skills among R\&D team members in terms of team identity, communication atmosphere, and harmony. Ng, K.Y., \&Chua, and R.Y. (2006) draw on the research results of McAllister (1995) to classify trust into cognitive trust and emotional trust. Cognitive trust depends on the assessment of one's past performance and reliability. Emotional trust derives from the social interaction 
with others, manifested as confidence in whether others can bring benefits to themselves.

\section{CONCLUSION}

At present, the research on team human capital has attracted the attention and research of more and more scholars. However, the research content mainly focuses on the two special groups of the senior management team and the entrepreneurial team. The main research contents are mostly the research on the relationship between team human capital and corporate performance, and employee motivation. For the concept, composition of team human capital, factors that influence the formation of team human capital, etc., further research is needed.

First, the concept of teamwork human capital is pertinent, and most scholars just put forward corresponding views based on their research content, and did not discuss the concept of team human capital in depth. Therefore, future research can focus on the research of theoretical frameworks and enrich human capital theory.

Second, in the existing research, the composition of the team's human capital is mainly measured from the perspective of demographic variables. There is a lack of measurement of individual aspects of team members.

The formation of team human capital mainly focuses on education investment, R\&D investment, and other aspects. There is less research on the interaction between the various components of team human capital. The R\&D team, as a team of knowledge workers, does not need to elaborate on the importance of knowledge in it. Although there are studies on interpersonal relationships and trust between employees and their willingness to cooperate and share knowledge, the existing researches lack the research on the impact mechanism of these factors on the human capital of the team. From the aspect of team building, we can discuss the factors that affect the formation of team human capital and promote the formation of team human capital.

\section{REFERENCES}

[1] Ge Yuhui. Research on the Relationship between Human Capital and Differentiation of Power Allocation of Top Management Team [J]. Enterprise Economy, 2011(10):9-14.

[2] Jiang Xiuzhen, Gu Qinxuan, Wang Lihong. Learn from mistakes and R \& D Team Innovation: Based on Human Capital and Social Capital[J].Management World, 2011(12):178-179

[3] Lu Hong, Li Xiaoqing, Xing Yanan. Research on the Relationship between Human Capital and Corporate Growth of Top Management Team-An Empirical Study Based on the Growth Enterprise Listed Companies [J]. Science and Technology Management Research, 2014, 34(4):157-162.

[4] Gao Suying, Xu Long, Ma Shuyan. The Relationship between Innovative Human Capital and Corporate Competitive Advantage: The Role of R\&D Team Member Configuration and Team Spirit [J].Science and Technology Management Research, 2016, 36(23):180-186.

[5] Li Jianjun, Li Danmeng. Characteristics of Entrepreneurial Team Human Capital and R\&D Investment of High-tech Enterprises-An Empirical Study Based on China's Growth Enterprise Market [J]. Soft Science, 2015, 29(3):79-83.

[6] Zhan Menglin. The Impact of Entrepreneurial Team Human Capital Structure on the Performance of Start-ups: An Empirical Study Based on the "New Three-Board" Startups [J]. Management and Administration, 2016(11):136-138. 